\title{
Assessing Workability Complaints in Mass Concrete Construction
}

by Billy $\mathrm{D}$. Neeley

Structures Laboratory

U.S. Army Corps of Engineers

Waterways Experiment Station

3909 Halls Ferry Road

Vicksburg, MS 39180-6199

Final report

Approved for public release; distribution is unlimited

Prepared for U.S. Army Corps of Engineers

Washington, DC 20314-1000

Under $\quad$ Work Unit 32768 